\title{
3 \\ Chiefly leadership in Fiji after the 2014 elections
}

\section{Stephanie Lawson}

'Chiefdoms are highly variable, but they are all about power.'

(Earle 2011, p. 27)

\section{Introduction}

The last quarter century has seen a significant decline of chiefly influence in Fiji's politics, albeit with some periods of enhanced status for the paramount symbol of indigenous Fijian traditionalism, the Great Council of Chiefs (GCC). This body, however, was abolished by decree under the military regime of Commodore Josaia Voreqe (Frank) Bainimarama in March 2012. The September 2014 elections held prospects for the restoration of chiefly authority and the role of traditionalism through the Social Democratic Liberal Party (SODELPA) led by Ro Teimumu Vuikaba Kepa, holder of a prominent chiefly title. A victory by SODELPA would also have seen the restoration of the GCC. With SODELPA's resounding defeat by Bainimarama's FijiFirst Party, such prospects have received a significant blow.

This chapter provides an account of chiefly leadership in national politics, beginning with a survey of Fiji's colonisation, the role of chiefs in the British colonial regime generally, and their domination 
of national politics up until 1987. The second section reviews the political dynamics surrounding chiefly leadership from 1987 until the Bainimarama-led coup of 2006. The final sections examine chiefly involvement in national politics in the lead-up to the 2014 elections and prospects for the future of traditional chiefly political leadership which, given the results, look somewhat bleak.

\section{British colonialism and chiefly rule}

In contrast with many other parts of the world, where colonial rule was imposed by force, the paramount chiefs of Fiji petitioned the British to establish a Crown Colony. This act also ensured that the leading chiefly clans, mainly from the south and east of the island group, were incorporated into the colonial administration and remained entrenched there throughout the colonial period. The Deed of Cession signed on 10 October 1874 was unconditional in terms of ceding authority to the British Crown but it came to be regarded as a charter of native rights, especially those of the chiefs, and a guarantee that these rights would always be paramount over those of settlers in the colony. This 'doctrine of paramountcy' came to underpin traditional chiefly institutions and has constituted the foundational principle from which indigenous nationalist claims proceed (Lawson 2004).

There was no traditional national political authority in pre-cession Fiji but, rather, a range of sociopolitical units that varied across the island group with different structures of authority and landholding practices. But if the sociopolitical groupings throughout the islands and their relationship to the land were complex and varied, it was the task of the colonial administration to simplify and rationalise them. Pre-existing structures therefore underwent something of a transformation, resulting in what is best described as a neo-traditional order (MacNaught 1982). This included the formalisation of the provinces as administrative units and the establishment of provincial councils presided over largely by chiefs.

At the apex of the colonial Fijian Administration was the Great Council of Chiefs or GCC. It had not existed prior to colonisation but arose initially when Fiji's first substantive colonial governor, Sir Arthur Gordon, summoned the high chiefs to a meeting. This event became a more or less annual affair and was in turn transformed into a formal 
advisory body. When the Legislative Council was established, leading chiefs were appointed to represent indigenous Fijians, with the initial nomination process conducted through the GCC. Reforms in the 1950s allowed a small number of 'commoners' to serve, but indigenous Fijians as a whole were not enfranchised until the early 1960s. The GCC continued to nominate two members of the legislative council until independence, when all seats in the new House of Representatives were filled through elections, albeit on a communal basis. The 1970 Constitution of independent Fiji also provided for a Senate with appointees nominated by the GCC comprising the largest bloc and with the GCC as a whole having a veto over any legislation affecting indigenous Fijian interests. At the same time, GCC membership widened to include all indigenous Fijians elected to the lower house as ex officio members.

The most prominent chiefs of the colonial period had been Ratu Sir Lala Sukuna and his protégé, Ratu Sir Kamisese Mara. Mara became chief minister in the colonial government, then prime minister at independence in 1970 and president from 1993 to 2000. Both Sukuna and Mara enjoyed high chiefly status in the traditional sphere, but both were also highly educated. Sukuna established the Native Land Trust Board, which rationalised the leasing of native land to IndoFijian tenant farmers, bringing benefits to both communities at the time (Norton 2005, p. 149). A number of other key chiefly figures who came to occupy high office benefitted from Sukuna's mentorship as well, including Fiji's first two indigenous governors-general, Ratu Sir George Cakobau and Ratu Sir Penaia Ganilau, as well as Ratu Sir Edward Cakobau, a leading politician in the transition to independence and after.

Colonial practices and institutions produced a certain cultural uniformity that provided the basis for an emergent indigenous national identity based squarely on respect for chiefly leadership. This was reinforced through the introduction of a substantial nonindigenous population from India to provide cheap labour for the colony's plantation economy. Gordon's paternalistic policies required commoner Fijians to remain in their own villages and under the control of their chiefs, thus preserving the 'Fijian way of life' in what Gordon, and most of his successors, saw as its 'natural state'. This remained largely the case until the Native Regulations were abolished in 1967, only three years before independence (Madraiwiwi 2005). 
Nayacakalou (1975, pp. 7-8) noted that with the emergence of a modern state a different kind of leadership may be required, challenging those who derived their leadership status from traditional sources.

Preservation of the Fijian way of life also meant that Indians were strictly segregated from indigenous Fijians in virtually every sphere of life. When political representation was introduced, Indians, Europeans and Fijians were all catered for separately, giving rise to communal (i.e. race-based) political representation and therefore communal electoral politics that persisted in one form or another right through to the promulgation of Fiji's 2013 Constitution.

The presence of a substantial 'alien' population contributed to an ideology not only of Fijian 'paramountcy of interests' over those of other population groups but also of chiefs as differentiating symbols of racial/ethnic identity and guardians of the vanua, a term understood as embodying a sacred connection between chiefs, land and people. This was strengthened rather than undermined by the widespread adoption of Christianity (lotu) among indigenous Fijians (Ryle 2012; Tomlinson 2002). Around 98 per cent of indigenous Fijians are Christian and of those about three-quarters are Methodists. Indo-Fijians remain predominantly Hindu while approximately 15 per cent are Muslim and 5 per cent Christian (Fiji Bureau of Statistics 2013).

\section{Chiefly politics and indigenous nationalism in independent Fiji}

Under the 1970 Constitution, the establishment of communal seats required that both candidates and electors be classified as indigenous Fijians, Indo-Fijians or General Electors (the latter mainly European and part-European but with small numbers of 'others', such as Chinese or other Pacific Islanders). Additional cross-voting seats modified strict communalism, but electoral politics was inevitably attuned to perceived communal interests. The National Federation Party (NFP) was essentially an Indo-Fijian party. The Alliance initially sought to embrace all communities, and attracted around 25 per cent of the Indo-Fijian vote in the first general elections of 1972, but it could not maintain this backing in a system so oriented to communal politics. Rather, the Alliance came to embody a reified notion of 'Fijian 
tradition', including the privileged role of chiefs in every sphere of political life from the village to the national level. However, it was challenged in the mid-1970s by an ultra-nationalist Fijian partythe Fijian Nationalist Party (FNP) - led by a disgruntled former Alliance member, Sakeasi Butadroka, who believed the Alliance under Mara was selling out indigenous Fijian interests to 'foreigners', and Indo-Fijians in particular (Lal 2012, p. 76).

The Alliance was never to recapture the popularity it enjoyed in the early 1970s. Butadroka had opened up an aggressive discourse that threatened to outbid the Alliance in catering to indigenous interests, thus forcing the Alliance to shift its own discourse in that direction. The Alliance nonetheless enjoyed the advantage underpinned by its traditional leadership, something that Butadroka as a commoner was unable to challenge effectively at that time. This was despite the fact that the GCC itself had, by the late 1970s, come to include in its membership chiefs of modest rank and non-chiefs from various walks of life (Norton 2009, p. 99).

Developments before the elections of 1987 saw the emergence of the Fiji Labour Party, led by Dr Timoci Bavadra. It grew out of both blueand white-collar trade union interests and attempted to promote a new discourse attuned to the rights and interests of all middle and lower socioeconomic groups. It became clear, however, that a split in the Indo-Fijian vote would guarantee an Alliance victory, thus prompting a coalition agreement between Labour and the NFP. In the meantime, the Alliance continued to warn of the dangers to indigenous Fijian interests, especially with respect to the land, if the Alliance and its chiefly leadership were to ever lose office. One senior figure argued:

[T] he chiefs represent the people, the land, the custom. Without a chief there is no Fijian society. When Fijian chiefs are attacked or criticized in whatever capacity - personal or political - it is the Fijian vanua which is also being criticized (quoted in Lawson 1996, p. 62).

Although these were not the only issues of importance during the campaign, the very idea of an overriding threat to indigenous Fijian land, traditional chiefly leadership and their very identity as indigenous Fijians, expressed through the vanua, dominated Alliance discourse. 
Following victory by the Labour-NFP coalition, nationalist rhetoric focused on the threat to everything that the vanua concept stood for. In the following weeks, an emergent Taukei movement (Taukei meaning, literally, 'owners') promoted an extremist nationalist agenda, fomenting civil disorder and violence against Indo-Fijians. Alliance leaders did little or nothing to calm the situation. The fact that indigenous Fijian rights and interests were triply entrenched in the 1970 Constitution, with a GCC veto the final block on any change, was never mentioned by Alliance or Taukei leaders.

When the third-ranking officer of the Royal Fiji Military Forces, Lieutenant-Colonel Sitiveni Rabuka, intervened less than six weeks after the elections by taking the coalition government hostage at gunpoint on the floor of the parliament, Alliance leaders professed shock and amazement. Despite denial all around that anyone but Rabuka and his immediate followers in the military were involved in the plot, there can be little doubt that key Alliance figures had prior knowledge of the plans. Rabuka certainly justified the coup in precisely the same general terms used by Alliance and Taukei figures alike - namely, the threat to the Fijian vanua posed by an 'Indian government' accompanied by the aggressive assertion of indigenous nationalist claims (Lawson 1996, p. 64).

There were, however, tensions within the forces aligned with the coupmaker, including some anti-Alliance/anti-Mara antagonism among Taukei members. Norton (2005, p. 153) observes that proponents of the more extreme Taukei/FNP ethno-nationalist vision of exclusivity have typically been commoners while Howard (1991, p. 358) notes that after the first coup, when Mara lost control of the GCC, extremists in the Taukei movement had sought to use it to thwart Mara's quest to regain control. Nonetheless, an interim administration comprising leading Alliance figures was endorsed by the GCC.

A few months later, however, Rabuka led a second intervention, claiming that the 'objectives' of his May coup, namely the permanent entrenchment of indigenous Fijian political and cultural dominance, had been compromised by the interim administration in making too many concessions to Indo-Fijians. On 7 October 1987, Rabuka declared Fiji a republic. But the chiefs were soon back at the helm. Mara became interim prime minister and Ganilau was appointed president. The Taukei movement remained a force, but a diminished one. 
It could not 'sustain an aggressive ethnic movement independently of the ideology that affirmed the legitimacy of chiefly leadership.' (Norton 2009, p. 103)

A fresh review of the Constitution led in due course to the promulgation of the 1990 Constitution of the 'Sovereign Democratic Republic of Fiji', approved by the GCC, dictating that all seats in the new parliament were to be communal, with the majority reserved for indigenous Fijians. Reforms to the GCC excluded many lesser chiefs and commoners, thereby boosting the power of higher chiefs. Around two-thirds of the Senate was to be made up of GCC appointees.

Since the Alliance had imploded in the aftermath of the 1987 coups, a new political party sponsored by the GCC was established. Called the Soqosoqo ni Vakavulewa ni Taukei (SVT), its very name embodied indigenous exclusivity. The NFP and Labour went their separate ways, both attempting to maintain a multiethnic character. The SVT, led by Rabuka, now turned civilian politician, won the 1992 elections but serious factionalism in the ranks led to another general election in 1994. The SVT won again but disunity remained a major problem. Although the SVT had initially been sponsored by chiefs, chiefly leadership within the party was rarely in evidence. Indeed, since the departure of Mara before the 1992 elections, no one of chiefly status, low or high, has held the office of prime minister, although high chiefs have continued to be appointed to the symbolic offices of governorgeneral or president. Mara himself became vice-president and then president of Fiji after Ganilau's death in 1993, a position he retained until the coup of 2000. Mara was succeeded by Ratu Josefa Iloilo and then by Ratu Epeli Nailatikau, who had been the military commander at the time of the 1987 coup (but was absent overseas when it took place). He is a son of the late Ratu Sir Edward Cakobau and is also Mara's son-in-law. He has since become one of Bainimarama's strongest supporters.

Despite, or perhaps because of, guaranteed political predominance, disunity continued to characterise intra-indigenous Fijian politics. This disunity together with continuing international opprobrium surrounding a constitution that discriminated so deeply against a population on grounds of race were no doubt factors that influenced a rethink of political arrangements. Racial discrimination had led to many skilled Indo-Fijians emigrating, taking the edge off the 
demographic issue of indigenous Fijians being 'swamped' by an immigrant race. After 1994, Rabuka initiated moves to review the Constitution, resulting in the 1997 Constitution of the 'Republic of the Fiji Islands'. Although introducing some open electorates, it retained a significant number of communal seats. Indigenous Fijian primacy of status was reflected in the retention of the GCC's restricted membership and enhanced privileges, which included the right to appoint the president and vice-president, although the number of senators nominated by the GCC was reduced. The GCC had been persuaded to endorse this new constitution by both Mara and Rabuka, an endorsement seen as essential for broader acceptance by indigenous Fijians. But the more extreme nationalists nonetheless saw it as a sell-out.

Opposition was heightened following the result of the 1999 elections, which saw Fiji's first and so far only Indo-Fijian prime minister, Labour's Mahendra Chaudhry, emerge as leader of a coalition which defeated an STV-NFP coalition led by Rabuka and long-standing NFP leader Jai Ram Reddy in a surprise result. The latter coalition, and the compromises it entailed, had inflamed nationalists further and split the indigenous Fijian vote. Chaudhry's cabinet was balanced and included Mara's daughter (and wife of Ratu Epeli Nailatikau), Adi Koila Nailatikau, elected to her father's old seat as a member of a new regionally based party that had joined the Labour-led coalition.

After a difficult year in office, during which issues concerning the renewal of leases on agricultural land further inflamed nationalist sentiment, the Chaudhry government was overthrown on 19 May 2000 in a coup led by failed business entrepreneur George Speight and a handful of disloyal soldiers from the military's Counter-Revolutionary Warfare (CRW) unit, who took government members hostage in the parliamentary compound. Their justification was once again the threat posed to indigenous Fijians by an 'Indian government'. But this was not a military coup, and it was not backed by the Republic of Fiji Military Forces (RFMF) commander Bainimarama. Ratuva (2011, p. 110), reports that some (unnamed) ethno-nationalist politicians had actually approached the military commander some time after the 1999 elections to ask that he lead a coup, but were met with refusal. By the end of the month, however, Bainimarama declared martial law in the absence of an effective government following the Speight 
intervention, sidelining President Mara. Following a complicated set of events, Mara's position as president became untenable and he eventually tendered a formal resignation.

Bainimarama also sidelined the GCC, which was split between pro- and anti-coup supporters. Norton (2009, p. 105) observes that dissent and rivalries had always been a feature of GCC meetings, but the impasse created by the coup was unprecedented. He further observes that the failure of leading chiefs to unite in support of a constitution they themselves had endorsed was partly due to a long-standing resentment among some Bauan chiefs over the continuing political pre-eminence of the Lauan paramount chief, Mara. Among the Bauans was Adi Litia Cakobau, daughter of the late Ratu Sir George Cakobau and a strong supporter of the Speight coup, who had previously served in the post1987 government. The GCC later accepted a court ruling that the 1997 Constitution remained the law of the land. In any event, a nationalist government went on to win two general elections held under its auspices, thereby dampening some of the nationalist opposition to the constitution's more liberal provisions. Two weeks after the 2000 coup, Bainimarama declared he was no longer willing to let the chiefs decide who should rule (Guardian 2000). This followed Speight's demands that the GCC be granted executive authority (Guardian 2000). These were rejected by Bainimarama, and Speight himself was to be sidelined soon enough.

The coup saw Mara's forced resignation as president and the appointment of a caretaker government led by Laisenia Qarase, a former GCC appointee to the Senate. Speight had agreed to this appointment, had relinquished his own claims to office and finally freed the hostages after accepting an amnesty agreement. However, he soon broke the terms of the amnesty, was arrested and subsequently faced trial for treason. He is now serving a life sentence.

The personal tipping point for Bainimarama was an attempted mutiny by a small number of CRW soldiers, which involved a plan to assassinate Bainimarama for his opposition to Speight. It very nearly succeeded, but was thwarted by Bainimarama loyalists. Eight soldiers were killed. Five from the CRW unit were beaten to death by loyalists. No one has ever been charged over the deaths. 
In the meantime, Qarase went on to win elections in 2001, espousing nationalist sentiments clearly aligned with those of Speight. Qarase's new government included members of a new party, the Conservative Alliance Matanitu Vanua (CAMV), set up by Speight and his supporters, which had won six seats. Speight won a seat from prison but soon lost it for non-attendance in parliament. Qarase's own party, the Soqosoqo Duavata ni Lewenivanua (SDL), had formed government in coalition with the CAMV (later absorbed into the SDL). Thus the new government rode what seemed to be a high tide of indigenous Fijian nationalism. Qarase also sought to ingratiate himself with the GCC by suggesting that the sovereignty of Fiji be shared between parliament and the GCC. His government also established an independent income stream for the GCC and work on a grand new building next to Government House commenced (Norton 2009, p. 106).

But Qarase failed to ingratiate himself with Bainimarama, and in fact provoked his implacable hostility by attempting to pave the way for the early release of the coup perpetrators and mutineers through the Reconciliation, Tolerance and Unity Bill, which could have provided an amnesty. For Bainimarama, the very idea of an amnesty for the coup perpetrators meant Qarase was contemplating the release of his wouldbe assassins. Bainimarama's relationship with Qarase had reached the point of no return. For his part, Qarase made several unsuccessful attempts to remove Bainimarama as head of the military (Lal 2012, pp. 29-30), no doubt contributing to Bainimarama's determination to remove him. Bainimarama subsequently campaigned strongly against the SDL in the May 2006 elections and although Qarase emerged victorious, Bainimarama refused to accept his government's legitimacy, charging it with corruption, incompetence and racism (Norton 2009, p. 107). These were the principal themes justifying the December 2006 coup.

In the final days before the coup, Qarase attempted to use the GCC to help resolve the confrontation with Bainimarama, but the latter refused to have the GCC involved. As Bainimarama announced his takeover, the GCC chair, the Tui Tavua, Ratu Ovini Bokini, highlighted his betrayal: 'You told the GCC you would protect this country. Now you have turned your back on God, the chiefs, our country and the church ...'. (quoted in Norton 2009). Bainimarama certainly promised to 
bring about not just a change of regime, but a revolution in political thinking and behaviour in Fiji that moved well beyond traditionalism and indigenous nationalism and all that these entailed.

\section{The retreat of traditionalism in post-2006 Fiji}

Qarase's SDL government was clearly based on a nationalist/ traditionalist ideology with close ties to the GCC, the Methodist church, provincial councils and other smaller groups and organisations (Ratuva 2011, p. 112). But another major institution that had previously been closely aligned with a nationalist ethos was the military itself, around 99 per cent of whose members were indigenous Fijians. Part of Bainimarama's task was to reorient the military away from that ethos, a task not without its difficulties given that a significant proportion of military personnel had probably voted for the SDL (Firth \& Fraenkel 2009, p. 117). This task required two key strategies: first, the purging of all elements among senior officers suspected of disloyalty; and second, the re-making of the military's corporate identity separate from, and indeed in opposition to, a nationalist/traditionalist identity (Lawson 2012).

Bainimarama's post-2006 military regime was determined to counter the anti-modernist elements in indigenous Fijian society, again through two key strategies: the political repression of oppositional opinion on the one hand, and the concerted engagement of indigenous Fijians through a major exercise in public relations on the other. The latter was boosted by long-overdue infrastructure works to upgrade roads and bridges, school buildings, water supplies and to extend electrification of villages. Constitutional change would also prove essential to Bainimarama's long-term vision, as we see shortly.

In the meantime, the relationship between the GCC and Bainimarama was deteriorating, even though GCC appointee President Ratu Iloilo had 'meekly accepted being shunted aside' by Bainimarama during the events of 2006, then 'ignominiously [accepted] re-appointment as President, and consequently doing all of Bainimarama's bidding' (Narsey 2012). In April 2007, matters came to a head when the GCC rejected the nomination of Bainimarama supporter Ratu Epeli 
Nailatikau for the vice-presidency. Bainimarama responded by suspending the GCC. In February 2008, new regulations for the GCC were introduced, designed to 'depoliticise' it. But this exercise became irrelevant as the GCC was never to meet again.

In April 2009, another major development occurred following a court case in which the coup of 2006 was declared illegal under the Constitution and Bainimarama's interim government invalid. Bainimarama promptly bade Governor-General Iloilo to abrogate the Constitution. Public Emergency Regulations (PERs) were introduced and Bainimarama commenced rule by decree while muzzling the media, trade unions, NGOs and the arch-nationalist Methodist church. The aim was to suppress not just racist/nationalist discourse but any criticism of the regime. The PERs were withdrawn in January 2012, ostensibly to allow public debate on a new constitution, but new amendments to an older public order act simply reinstated them in another form (Welch 2012).

In March 2012, Bainimarama abolished the GCC as an anachronism that could serve no positive function in the new Fiji under construction by his regime. The GCC, he said, 'is a product of our colonial past and Fiji must now focus on a future in which all Fijians are represented on the same basis' (quoted in Ratuva 2013, p. 175). Another product of the colonial past were the privileges chiefs enjoyed as major beneficiaries of rental income generated through native land leases. Part of the logic was that chiefs required this income to meet their traditional obligations as chiefs in funding projects for their communities. There had been criticism over the years, however, that many chiefs kept most of the money for themselves. Under the Bainimarama regime, new provisions were made for distributing land rental monies on an equal basis to all members of the landowning units, with chiefs to receive no more and no less than any other member (Fiji iTaukei Land Trust Board 2010; Sakai, this volume).

The abolition of the GCC in 2012 coincided with the announcement of an independent constitutional review committee to draft a new constitution. In the event, Bainimarama rejected many elements of the draft, believing it pandered to the very same groups that had previously brought the country to grief. The draft was therefore amended substantially to reflect the regime's own vision and the new Constitution promulgated in September 2013. A decree relating to the 
registration of political parties had been issued in January 2013, allowing parties only 28 days to register, severely restricting sources of funding, disqualifying civil servants and trade union officials from candidature as well as undischarged bankrupts, and those who had served a prison sentence for more than six months in the previous five years. Parties were required to use English names, have multiracial membership, and were prohibited from advocating 'racial or religious hatred, incitement or vilification' (Fiji Elections Office 2014a).

The conviction of Qarase in 2012 on corruption charges relating to activities back in the 1990s disqualified him from candidature, while the ruling on party names disallowed the use of Soqosoqo Duavata ni Lewenivanua. The party was renamed 'Social Democratic Liberal Party', an interesting assortment of monikers designed to at least retain ' $S$ ', ' $D$ ' and ' $L$ ' in its acronym, SODELPA. Its new leader was Ro Teimumu, who had succeeded to the paramount chiefly title of Roko Tui Dreketi on the death of her older sister, Ro Lady Lala Mara (wife of Ratu Mara). She had been appointed a senator in 1999 and then served in the Qarase government from 2001 while also a member of the GCC. Chiefly leadership therefore featured once again in Fiji's foremost traditionalist political party.

A statement by Ro Teimumu and the Tui Cakau, Ratu Naiqama Lalabalavu, issued as a critical response to the 2013 Constitution on the 139th anniversary of the signing of the Deed of Cession, referred, among other things, to the regime's undermining of 'group rights' in relation to land and appealing to international instruments underscoring respect for historical treaty obligations, while also claiming that the group rights of indigenous Fijians should be a concern 'of all right thinking Fiji citizens who proudly share in the ownership of its unique identity' (Statement from Rewa and Cakaudrove chiefs 2013).

This last appeal can scarcely have persuaded the great majority of Indo-Fijians to defer to the very institutions of indigenous Fijian tradition that had so often been used to cast them in the role of second-class citizens. Rather, Indo-Fijian political support had swung firmly behind the Bainimarama regime, which promised to make them fully equal citizens in a new Fiji. What is more surprising, however, is the extent to which indigenous Fijians also shifted their support to Bainimarama in the 2014 elections. 


\section{The 2014 elections}

The 2013 Constitution had abolished communal voting and the elections were conducted on the basis of one voter, one vote, one value under an open list proportional representation system with every citizen over 18 years of age enfranchised on a single national register. The main parties contesting the elections were Bainimarama's FijiFirst, SODELPA, the Fiji Labour Party, the National Federation Party, and the People's Democratic Party (a new party sponsored by the liberaloriented Citizens' Constitutional Forum). But the main contest was between FijiFirst and SODELPA, the former promising a new, modern, secular Fiji free of the crippling legacies of a racially divided past.

FijiFirst also promised a continuation of development projects that had brought tangible benefits to many towns and villages around the islands and which no doubt played a significant part in attracting indigenous Fijian support. But Bainimarama's efforts to eliminate racist discourse and to curb the power and privileges of chiefs played its part among indigenous Fijians as well as Indo-Fijians. It would be too much to claim that racist discourse has disappeared, as various rather vicious blogs in unregulated cyberspace attest, but public expression of racist/nationalist views and scare tactics were certainly repressed. This was a positive feature of the campaign, although it came at the expense of freedom of expression.

SODELPA, while declaring its sensitivity 'to the traditions of all communities who call Fiji home' (SODELPA 2014a), nonetheless promoted the nationalist cause as far as it could. The manifesto called for the restoration of the GCC and other chiefly privileges lost under the Bainimarama regime, again appealing to the International Labour Organization (ILO) Convention 169 and the UN Declaration on the Rights of Indigenous Peoples, 2007.

It is important to put to rest the fears of our native Fijians about what they see as the erosion of their rights, interests and place in the islands they first populated. The principles of the UN Declaration and the ILO Convention are not racist ... They are internationally recognized platforms for indigenous populations everywhere ... (SODELPA 2014a). 
SODELPA also made much of Bainimarama's support of Fiji as a secular state in which no particular religion was to be elevated over others. In contrast, SODELPA promoted Fiji as a 'Christian state', while denouncing the 2013 Constitution as 'Godless' (SODELPA 2014b).

Neither the NFP nor Labour could match Bainimarama's appeal to both Indo-Fijian and indigenous Fijian voters. Labour, with just 2.4 per cent of the vote, failed to secure a single seat, while the NFP managed just 3 seats with 5.5 per cent. SODELPA gained 28.2 per cent of the votes and 15 seats (Fiji Elections Office 2014b). The victory by Bainimarama's FijiFirst, securing almost 60 per cent of the vote and 32 seats, can only be described as resounding. There were, inevitably, claims of electoral fraud, but international observers declared the elections largely free and fair, at least procedurally. The main limitation on 'free and fair' was not ballot-rigging, of which there was little evidence, but the muzzling of the media, political parties and others with critical opinions to voice.

Even given this, it was remarkable that a country mired so long in racially oriented politics could produce a stunning victory for a leader who had consistently opposed any form of race-based discourse, repudiating virtually everything that indigenous Fijian nationalists had stood for. That he did so largely through the military, an institution that historically has been as much a part of the traditionalist/nationalist superstructure of Fiji as any other, remains a paradox.

\section{Conclusion}

Traditional chiefly leadership has been a powerful political force in Fiji's national politics from the moment the Fiji islands became a unified state entity under colonial rule. Initially institutionalised through the colonial administrative structure, supported by a strong traditionalist ideology and allied at times with an uncompromising indigenous nationalism, paramount chiefs held all the higher offices of the Fijian state until 1987. The Great Council of Chiefs maintained an authoritative presence in government until it was suspended and then finally abolished by the Bainimarama regime in 2012. The only remaining high official position still held by a leading chief is the presidency, which the present incumbent holds only by virtue 
of his support for Bainimarama. The only other official position in the parliamentary system now held by a high chief is Leader of the Opposition.

The future of traditional chiefly leadership in Fiji's national politics therefore looks rather bleak. Bainimarama has not only routed the chiefly establishment, but has also achieved considerable success in quashing nationalist discourses. Although achieved partly through suppression, the apparent strength of electoral support for Bainimarama's vision of a modern, secular Fiji can scarcely be denied. At the same time, it would be foolish to claim that the ideas and beliefs underpinning racism in Fiji - evident among all communities - have been eliminated, as attested by ongoing diatribes in the blogosphere. Nor has the chiefly system as such disappeared. It is likely to continue to hold a valued place among indigenous Fijians in ceremonial life, and may well maintain a strong presence in local and provincial politics. But it seems unlikely that chiefs will ever dominate national politics to the extent that they once did, especially given the persistent tensions within their own ranks. Having said that, Fiji's politics never fail to surprise, and what seems unthinkable at one historical moment may well come to pass at another.

\section{References}

Earle, T 2011, 'Chiefs, chieftaincies, chiefdoms, and chiefly confederacies: power in the evolution of political systems', Social Evolution and History. vol. 10, no. 1, pp. 27-54.

Fiji Bureau of Statistics 2013, 'Population by religion - 2007 census of the population'. Viewed 20 November 2014 at www.statsfiji.gov.fj/ index.php/social/9-social-statistics/social-general/147-religion.

Fiji Elections Office 2014a, 'Political Parties Decree'. Viewed 26 November 2014 at www.electionsfiji.gov.fj/political-partiesdecree/.

Fiji Elections Office 2014b, 'Final results for the 2014 general election'. Viewed 26 November 2014 at www.electionsfiji.gov.fj/2014election-results/. 
Fiji iTaukei Land Trust Board 2010, 'Land ownership structure'. Viewed 26 November 2014 at www.tltb.com.fj/index.php?option=com content \&task $=$ view $\&$ id $=67 \&$ Itemid $=98$.

Firth S and Fraenkel J 2009, 'The Fiji Military and Ethno-Nationalism: Analyzing the Paradox', in S Firth, J Fraenkel and BV Lal (eds), The 2006 military takeover in Fiji, ANU E Press, Canberra, pp. 117-38.

Guardian 2000, 'Fiji festers as coup talks fail', 4 June. Viewed 24 November 2014 at www.theguardian.com/world/2000/jun/04/fiji. theobserver.

Howard, M 1991, Fiji: Race and politics in an island state, UBC Press, Vancouver.

Lal, B 2012, Fiji before the storm, ANU E Press, Canberra.

Lawson, S 1996, Tradition versus democracy in the South Pacific: Fiji, Tonga and Western Samoa, Cambridge University Press, Cambridge.

Lawson, S 2004, 'Nationalism versus constitutionalism in Fiji', Nations and Nationalism, vol. 10, no. 4, pp. 51938.

Lawson, S 2012, 'Indigenous nationalism, "ethnic democracy" and the prospects for a liberal constitutional order in Fiji', Nationalism and Ethnic Politics, vol. 18, no. 3, pp. 293-315.

MacNaught, TJ 1982, The Fijian colonial experience: A study of the neotraditional order under British colonial rule prior to World War Two, Australian National University Press, Canberra.

Madraiwiwi, J 2005, 'Governance in Fiji: the interplay between indigenous tradition, culture and politics', Keynote Address, conference on the 'Pacific, globalisation and governance', The Australian National University, Canberra, 26 October. Viewed 19 November 2014 at press.anu.edu.au/ssgm/global_gov/mobile_ devices/ch15.html.

Narsey, W 2012, 'Ghai's dilemma: to be more than a tape recorder', 21 May. Viewed 25 November 2014 at narseyonfiji.wordpress. com/2012/05/21/ghais-dilemma-to-be-more-than-a-tape-recorder/. 
Nayacakalou, RR 1975, Leadership in Fiji, Institute of Pacific Studies, University of the South Pacific, Suva.

Norton, R 2005, 'A paradox of tradition in a modernising society: Chiefs and political development in Fiji', in A Hooper (ed.), Culture and sustainable development in the Pacific, ANU E Press, Canberra, pp. 142-158.

Norton, R 2009, ' The changing role of the Great Council of Chiefs', in S Fraenkel and BV Lal (eds), The 2006 military takeover in Fiji: A coup to end all coups?, ANU E Press, Canberra, pp. 97-116.

Ratuva, S 2011, 'The military coups in Fiji: Reactive and transformative tendencies', Asian Journal of Political Science, vol. 19, no. 1, pp. 96-120.

Ratuva, S 2013, Politics of preferential development: Transglobal study of affirmative action and ethnic conflict in Fiji, Malaysia and South Africa, ANU E Press, Canberra.

Ryle, J 2012, My God, my land: Interwoven paths of Christianity and tradition in Fiji, Ashgate, Farnham.

SODELPA 2014a, Manifesto. Viewed 26 November 2014 at sodelpa. org/SODELPA-Manifesto-LR.pdf.

SODELPA 2014b, 'Secular State'. Viewed 26 November 2014 at www. facebook.com/sodelpa/posts/1397324750488161.

Statement from Rewa and Cakaudrove chiefs (2013). Viewed 5 December 2014 at www.coup5.com/2013/10/the-statement-fromrewa-and-cakaudrove.html.

Tomlinson, M 2002, 'Sacred soil in Kadavu, Fiji,' Oceania, vol. 72, no. 4 , pp. $237-56$.

Welch, D 2012, 'Fijians "double-crossed" over lifting of laws', Sydney Morning Herald, 11 January. Viewed 26 November 2014 at www. smh.com.au/world/fijians-doublecrossed-over-lifting-of-laws20120110-1ptm3.html. 
This text is taken from The People Have Spoken: The 2014 Elections in Fiji, edited by Steven Ratuva and Stephanie Lawson, published 2016 by ANU Press, The Australian National University, Canberra, Australia. 